\title{
The short-term costs of local content requirements in the Indian solar auctions
}

\author{
Benedict Probst ${ }^{1}$, Vasilios Anatolitis $\mathbb{1}^{2}$, Andreas Kontoleon ${ }^{1}{ }^{\circledR}$ and Laura Díaz Anadón ${ }^{1}$
}

\begin{abstract}
Developing and emerging economies are implementing local content requirements to spur domestic manufacturing, though their costs and benefits are not well understood and difficult to quantify. Here, we provide an empirical assessment of the short-term costs of local content requirements using a credible counterfactual. We analyse data on government-run solar photovoltaic auctions held in India between 2014 and 2017 and exploit the fact that not all of the auctioned contracts entailed local content requirements. We find that local content requirement policies resulted in a $\sim 6 \%$ per $\mathrm{kWh}$ increase in the cost of solar photovoltaic power generated from those projects when compared to similar projects not subject to the same local content requirement policy. During this three-year time period, Indian solar panels remained around $14 \%$ more expensive than international panels. We found some evidence of short-term increases in domestic manufacturing capacity, yet during this short period Indian firms did not increase market share or break into export markets.
\end{abstract}

$\mathrm{n}$ order to meet the climate and development targets set out in the Paris Agreement and the Sustainable Development Goals, countries around the world have been implementing policies to decarbonize the electricity sector through a greater deployment of renewable power generation ${ }^{1}$. Yet many countries are interested in renewable power generation not only to advance environmental outcomes but also to improve economic competitiveness ${ }^{2}$ by capturing a share of the growing market for low-carbon technologies. This market is projected to grow to US $\$ 6.4$ trillion by 2023 , with solar technologies expected to constitute the largest share of value of the clean energy technologies market ${ }^{3}$. The idea that localizing clean technology industries (that is, manufacturing clean technologies locally) might be possible for developing and emerging countries, at least in some contexts, is partly inspired by China's success in building competitive domestic wind and solar power manufacturing industries ${ }^{4,5}$ and by the decades-long academic literatures on national and technology innovation systems, ${ }^{6}$ catching up ${ }^{7}$ and related diversification ${ }^{8}$, among others ${ }^{9-11}$. Recently, there has also been a renewed interest in industrial policy, particularly in the case of green technologies ${ }^{12-14}$

In this context, local content requirements (LCRs) play a central role in the efforts of many governments, particularly those in developing and emerging economies, which account for $71 \%$ of all LCR measures introduced globally since $2008^{15}$. The main driver of LCR policies is that governments consider them useful to localize (at least a part of) the value chain for a particular technology. Even a partial localization of a value chain could help accelerate regional green growth and generate cross-sectoral spillovers and additional associated socio-economic benefits ${ }^{16}$. LCRs involve the requirement to source a certain percentage of intermediate goods from domestic manufacturers or service providers. Since 2008, more than 140 new LCRs have been introduced to boost domestic industrial performance and employment in a wide range of sectors, from the automotive to the extractive sector, with the majority of LCR policies being found in the energy sector ${ }^{17,18}$. China had LCRs between 1997 and 2009, Canada (in the province of Ontario) between 2009 and 2013 and South Africa, Brazil, Russia and Argentina, among others, continue to have LCRs in various clean technologies ${ }^{19-22}$. In spite of the fact that LCRs are illegal under World Trade Organization (WTO) rules, these policies exist because countries either delay suing countries putting in place LCRs or decide not to sue them because of other economic or geopolitical reasons. But while LCRs are illegal under WTO rules, they may be legal when linked to government procurement ${ }^{23}$. For instance, India abolished LCRs in 2017 due to WTO rulings, yet plans on circumventing such rules for $12 \mathrm{GW}$ of solar photovoltaics (PV) by requiring that public bodies purchase the electricity generated by projects that are obliged to use only domestically manufactured cells and modules ${ }^{24}$.

The existing literature on the cost and benefits of LCRs is limited to two main strands. The first concerns qualitative analyses of the legal and political aspects of LCR policies (for example, compliance with WTO laws) ${ }^{20,23}$. The second undertakes theoretical or simulation based (ex ante) analysis of the possible impacts of LCRs using computable general equilibrium models predicting theoretical impact of LCRs on component prices and employment, among other factors, under a wide range of assumptions and simplifications ${ }^{25}$. Yet despite the theoretical interest in the effects of LCRs and their relatively widespread use in many countries, there is scant robust 'empirical' evidence on the actual cost and short-term benefits of some of these green industrial policies designed to meet environmental and industrial competitiveness goals.

In this article, we address this gap in the literature by providing robust empirical evidence on the costs of LCRs in the renewable sector in India. We exploit a feature of the Indian solar auctions that can be used as a quasi-experiment to estimate the cost of LCRs. Using the cost estimates from the auction, we compute the additional cost of Indian modules (versus international modules) and the entire cost of the programme to the Indian government. We also explore whether projects subject to the LCR had a lower realization rate, which is a common worry in policy circles (that is, that national supply chains will not be well developed, leading to delays or even cancellations of projects). Beyond exploring the cost to the local government, we also briefly investigate the potential associated (short-term) manufacturing and innovation benefits, as LCRs 
a

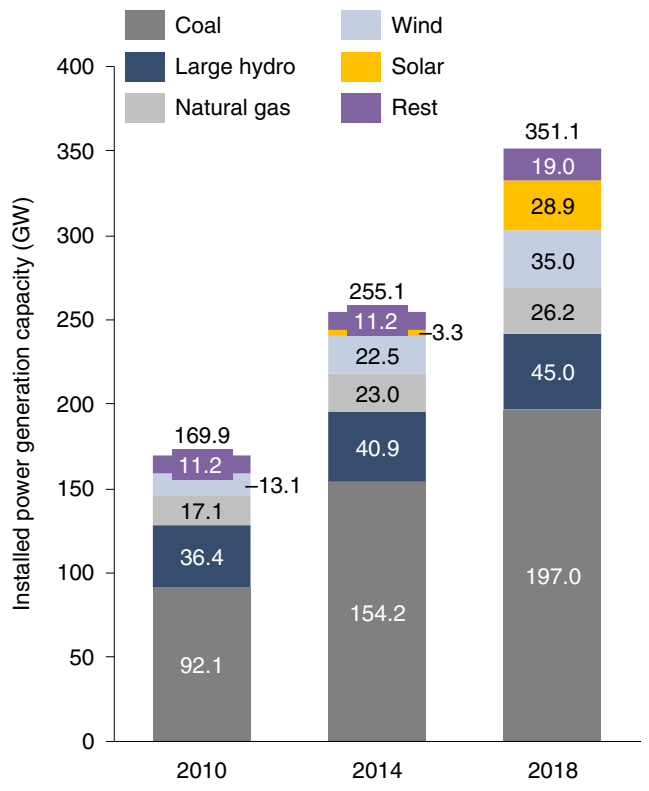

b

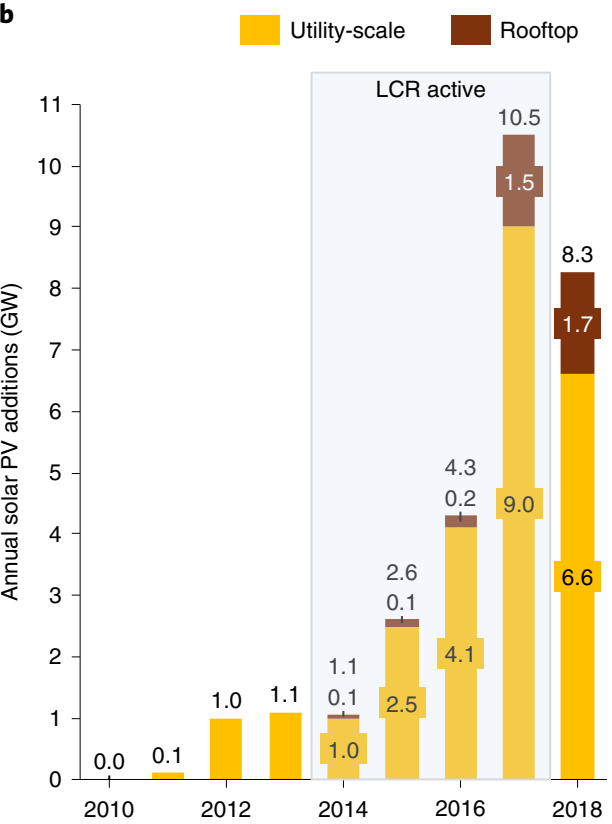

Fig. 1 | Energy mix in India and annual PV additions. a,b, Installed power generation capacity in India (a) and annual PV additions in India (b) (2010-2018); based on data from Climatescope ${ }^{51}$, India Infrastructure Research ${ }^{52}$ and Mercom ${ }^{53}$. a, India has more than doubled its power generation capacity from 2010 to 2018 to keep up with population and economic growth. This increase primarily stems from an increase in coal and renewable power generation capacity through wind and solar PV. b, The large increase in solar PV (b) was largely driven by the (Jawaharlal Nehru) National Solar Mission (NSM), a programme launched by the Indian government with the aim to reach $100 \mathrm{GW}$ installed capacity of solar PV by $2022^{54}$. The expansion was primarily driven by utilityscale solar PV, but rooftop solar has played an increasingly important role in recent years.

are commonly introduced with industrial policy goals in mind. We find that LCR policies resulted in a $\sim 6 \%$ per $\mathrm{kWh}$ increase in the cost of solar PV power generated from projects subject to LCR when compared to similar projects not subjected to the same LCR policy. This additional cost adds up to between US\$69 million and US\$88 million per installed GW of solar PV under the LCR policy. During this three-year period, Indian solar panels remained around $14 \%$ more expensive than international panels but saw the same relative cost decline of $60 \%$ as international panels between 2014 and 2018. Yet projects subject to LCRs had the same realization rate as all other projects, indicating that those projects using more components from India did not suffer additional delays. We found some evidence that the LCR policy is associated with substantial short-term increases in domestic solar PV patenting and installed manufacturing capacity. However, during this short period Indian firms have neither increased their domestic market share nor broken into export markets.

\section{Increases in the cost of solar power in India due to LCRs}

Auctions were implemented by the central government on both national and state levels between 2014 and 2017, but two auction types were active simultaneously: some auctions were subject to LCRs and some were not (for a full discussion of the Indian solar auctions see the Supplementary Note 1). Importantly, firms were able to participate in both auction types. This coexistence in time and national jurisdiction allows us to use the auctions without LCRs as a counterfactual for the auctions in which the firms making the bids were required to source all solar cells and modules locally in India.

In order to study the additional power generation cost that may have resulted from the introduction of the LCR policy, we collected project-level data on bids, bidding firms and other outcomes across 28 solar auctions in India that took place between 2014 and 2017 (see Supplementary Figs 1-4 for more detail on the dataset). Our data cover all central government-run solar PV auctions implemented during 2014-2017 where LCR auctions were implemented in parallel with non-LCR auctions. Our data cover around $60 \%$ of all government-run auctions; we omit the other $40 \%$ as there is no appropriate counterfactual. These LCR and non-LCR auctions were implemented across 10 states and also on the national level, consisting of around $21.7 \mathrm{GW}$ of bid capacity (of which $6.5 \mathrm{GW}$ was awarded) accounting for around half of the solar additions in India during this time period and around 5\% of India's total installed power capacity. LCRs were an important feature of these auctions. We study the outcomes of the second phase of the country's major solar power programme, the (Jawaharlal Nehru) National Solar Mission (NSM) (2014-2017), since in the first phase (2011-2013) the LCRs were not binding. An overview of the installed capacity in India and annual PV additions in India can be found in Fig. 1a,b, respectively.

We used two empirical specifications to test whether LCRs increased the cost of renewable power bids. First, as an exploratory exercise, we ran a pooled regression that included open and LCR auctions (Supplementary Table 1). Yet this specification suffers from a possible selection bias, as firms that self-select into either the open or LCR auctions may have different characteristics. For instance, inexperienced local companies might self-select into LCR auctions and avoid open auctions due to stiffer international competition. If the LCR auctions then exhibit higher prices than the open auctions, the result might not be caused only by higher domestic module prices but also-potentially_by the local companies having less experience vis-à-vis international companies. Hence, this analysis could overestimate the impact of LCRs on observed bidding prices, as the latter arise partly from firm characteristics and not solely from the policy itself. To address this possible self-selection bias, our main analysis employs a Heckman two-stage selection model (discussed in detail in the Methods section).

We collected detailed firm-level data from Mergent Intellect ${ }^{26}$, a market research firm, on all 85 firms that participated in the 
a

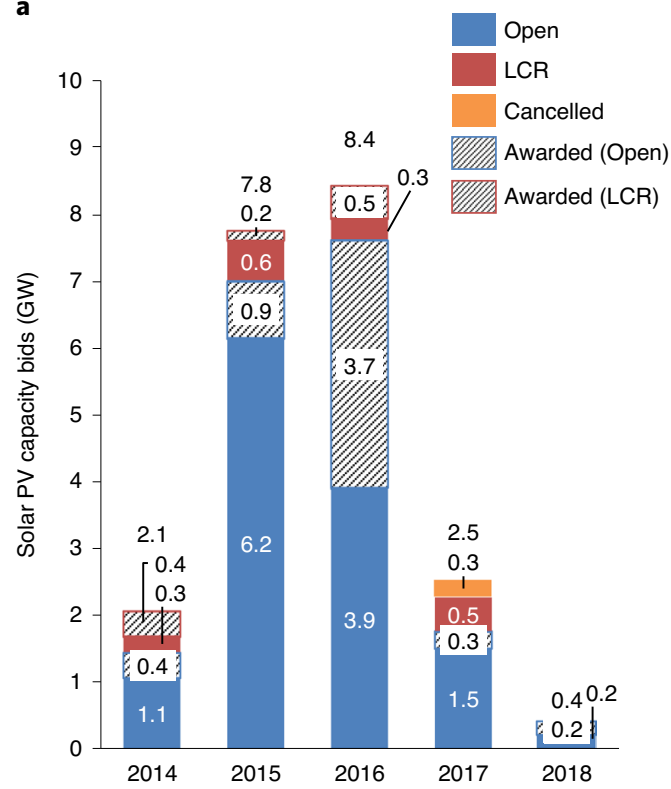

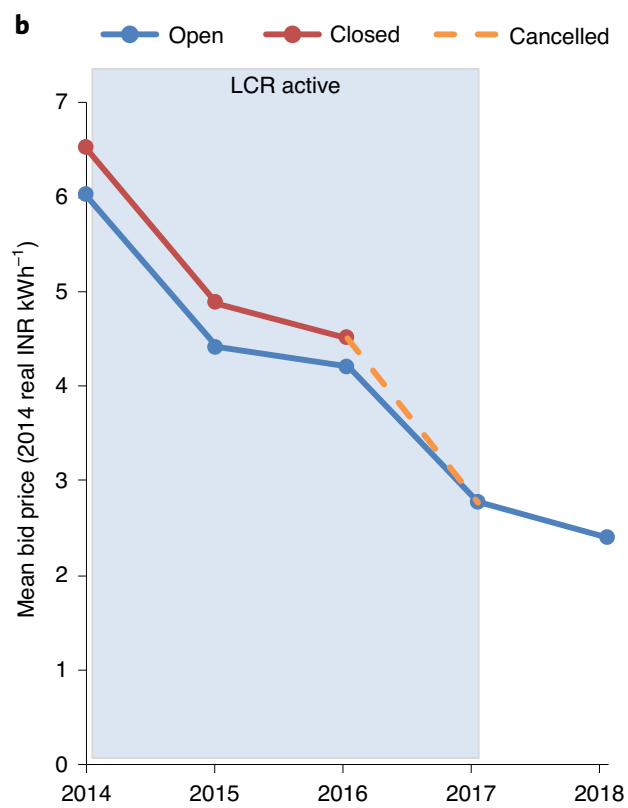

Fig. 2 | Solar capacity bids and mean bid prices. a, Solar capacity bids in our dataset (2014-2018). b, Mean bid prices (2014-2018). The area shaded in grey indicates the time when the LCR policy was active. The lines connecting the points serve only as a guide to the eye.

auctions. These firms comprise all major solar PV firms active in India. The data include relevant information for our analysis, including firm size (in number of employees) and whether the firm is state-owned or not, had gathered experience in the first phase of the NSM or not, is local or international, manufactures its own panels or not and has its primary business in renewable power generation or elsewhere (Supplementary Table 2). We undertook our analysis using two datasets, one using all bids and another using only winning (that is, awarded) bids. We used the latter as a robustness check to determine whether the estimates of the additional power cost from LCRs differ between the winning and the full set of bids. As the Indian government covers the difference between the local retail power price and the awarded solar auction bids, only awarded bids are of interest to the policymaker from a total cost perspective. An overview of the solar PV capacity bids in the programme (2014-2017) is shown in Fig. 2a, and mean bid prices across the auction windows are depicted in Fig. 2b. We also provide additional robustness checks in Supplementary Tables 5 and 6. Before turning to the additional costs from the introduction of LCRs, it is important to note (given the relatively scarce literature on India's solar auctions ${ }^{27}$ ) that the bid prices in both types of auctions (subject to LCRs or not subject to LCRs) went down by around $60 \%$ between 2014 and 2018, consistent with big decreases in auction prices in other countries ${ }^{28}$ due to a combination of technological change, institutional learning and learning-by-doing in project construction and finance. The last bid in the 2017 LCR auction round was later cancelled due to a WTO ruling. While the last bid round in 2017 saw similar bidding results between open and LCR auctions, this should not necessarily be interpreted as a sign of the narrowing of the price gap between open and LCR auctions, due to differences between the auction types in 2017 . The primary difference was that the capacity auctioned off in the LCR auctions in 2017 was almost twice as large as that in the open auctions, and the auctions were held on a national level, which is associated with lower prices given that firms are free to choose the location of the solar farm (leading to lower land prices and greater competition from engineering, procurement and construction (EPC) contractors and developers). In addition, the LCR auction saw much greater competition than the open auction. Finally, there was only one awarded bid in 2017 in the LCR auction, likely biasing the results downwards given that only the lowest bid was chosen, whereas in the other years several bids were selected.

We now discuss the analysis of the costs associated with the LCR. The first stage of our Heckman model can be seen in Table 1. Our regression results indicate that firms participating in LCR auctions had more experience in the first round of the NSM and had energy production as their main business (as opposed to merely having recently diversified into the energy sector, but continuing to mainly operate in a related sector) when compared to the firms that participated in the open solar auctions. More importantly, our 'Indian $\times$ Manufacturer' interaction term is highly significant $(p<0.01)$, which indicates that (as one might expect) Indian firms with PV manufacturing capabilities self-selected into LCR auctions, whereas international manufacturers were more likely to self-select into the open auctions. As local manufacturers do not have the economies of scale of international manufacturers, one might expect them to have higher module costs and thus be associated with higher bid prices.

We find that LCRs increased bid prices by $5.3-5.9 \%$ across all bids and by $6.0-6.1 \%$ for the awarded bids (Specifications (2)-(5) in Table 2). Cumulative experience of the developer reduced bid price, likely because of economies of scale and learning-by-doing. Whether SECI or NTPC was the offtaker did not have a price effect across all bids, but SECI tends to be associated with slightly higher bid prices of $1.8 \%$ across awarded bids, indicating that SECI has a higher perceived financial risk. Neither solar parks, competition within the auction nor differences in solar irradiation is associated with changes in bid price. Solar irradiation is similar across the Indian states in which solar auctions were held, likely driving this outcome.

\section{Higher cost of domestically manufactured PV modules}

We next use detailed project-level data from the International Renewable Energy Agency (IRENA) ${ }^{29}$ on the average investment cost of utility-scale solar PV projects in India to calculate the additional cost that developers had to pay for locally manufactured modules (which includes cells). We make the simplifying but reasonable assumption that the main difference between the open auctions and 
Table 1 | Heckman selection regression showing the characteristics of firms that self-select into LCR auctions versus open auctions

Dependent variable (1 indicates participation in LCR auction only or in both auction types, 0 indicates participation only in open auction)

\begin{tabular}{lll}
\hline & All bids & Awarded bids \\
\hline & $\mathbf{( 1 )}$ & $\mathbf{( 2 )}$ \\
\hline Employees & $-0.020(0.035)$ & $-0.036(0.050)$ \\
SOE & $-5.680(250.618)$ & $-6.284(551.271)$ \\
Manufacturer & $-1.063^{\star \star \star}(0.413)$ & $-6.313(661.0289)$ \\
\hline Indian & $0.006(0.231)$ & $0.030(0.347)$ \\
Indian×Manufacturer & $1.737^{\star \star \star}(0.475)$ & $7.36(661.029)$ \\
Energy focus & $0.597^{\star \star}(0.239)$ & $0.095(0.358)$ \\
Part_JNNSM_1 & $0.605^{\star \star \star}(0.232)$ & $0.824^{\star \star}(0.414)$ \\
Inverse Mill's ratio & $-0.045^{\star \star}(0.021)$ & $-0.012(0.016)$ \\
Sigma & 0.064 & 0.025 \\
Rho & -0.715 & -0.492 \\
\hline
\end{tabular}

Employees is the log number of employees of the company. SOE refers to Indian state-owned enterprise (SOE). Manufacturer is equal to 0 or 1 and indicates whether the company has manufacturing capabilities (opposed to merely project development, for instance). Indian refers whether the company was founded in India or is a foreign firm operating in the country. Indian $\times$ Manufacturer is an interaction term. Energy focus is equal to 0 or 1 and indicates whether the company has its main business in energy or in another field (for example, road building). Part_JNNSM 1 is a dummy equal to 1 if the company had already participated in the first round of the Jawaharlal Nehru National Solar Mission (JNNSM) and to 0 if it had not. Standard errors are shown in parentheses. Inverse Mill's ratio, sigma and rho reported are from the full specification (5 and 10 in Table 2). ${ }^{\star} p<0.10{ }^{* \star} p<0.05^{\star \star \star} p<0.01$

the closed auctions (that is, auctions subject to LCRs) was the cost of the solar panels, as opposed, for instance, to increased financing cost due to local content and higher risk. As firm size was similar across the open and closed auctions, this is a credible assumption to make. Given that over the four-year period covered by our analysis, average module prices made up $42 \%$ of the total investment cost of utility-scale PV projects in India ${ }^{29}$ (Fig. 3a), this implies that panels subjected to LCRs were on average around $14 \%$ more expensive (ceteris paribus) than panels that were not subjected to LCRs during the period studied (Fig. 3b), leading to a $6 \%$ difference in average bid prices between non-LCR auctions and LCR auctions.

We also find that in percentage terms the gap between price of the auctions with LCRs and non-LCRs did not close over the four-year time frame of our data (see Fig. 2b), which is not surprising as four years is a relatively short period.

\section{The total cost of the LCRs to the Indian taxpayers}

We next estimate how much additional cost the Indian government incurred due to increased cost for the solar PV through LCR auctions compared to open auctions. Unlike other renewable deployment subsidies, which to a large extent end up being paid indirectly by retail electricity consumers ${ }^{30}$, in this case the cost of the solar power is borne directly by the Indian government. The reason for this is that, although the power generated by the solar plants is purchased by the respective utilities in the state where the auction took place, the Indian government (through taxation) covers the price difference between the average power purchasing cost of the utilities and the cost of solar power ${ }^{31,32}$.

To estimate the possible range of the additional cost borne directly by the Indian government due to LCRs, we use the average estimates from our Heckman regression (Table 2) of the additional cost of power of LCR bids when compared to the open bids. We compute this overall cost to the Indian government via a net present value (NPV) model, in which we discount all future payments from the Indian government to solar power plant owners and compare the cost to the clean technology budget in India. For the specific parameters used, please consult the Methods section. We estimate that the Indian government will cover between US\$69 million and US\$88 million per installed GW of solar PV under the LCR policy. As the LCR bids we analysed in this study add up to $0.8 \mathrm{GW}$, this equates to between US\$55 million and US\$70 million in total.

\section{Realization rates for LCR projects and open projects}

For each of the 114 awarded bids (out of 277 bids made in total), we also collected information on whether projects were built. This is also a contribution to the existing literature on auctions for renewables, as there is scant information on the 'realization rates' of such projects, with most studies relying on bid (auction) data but not following through to determine whether the projects were completed. For instance, in the Brazilian wind auctions LCRs were shown to have a negative influence on realization rates $^{33}$.

Collection of data from various governmental sources ${ }^{34}$ revealed that the LCR component has not decreased or increased the realization rates of the projects when compared to the auctions without LCR requirements. For both categories of bids (under closed versus open auctions), $97 \%$ of the projects were built, with a small fraction still being under construction. However, future work should explore whether the completion time, the quality of the projects and the 'capacity factor' differed between solar PV projects built under each of the two auction types.

\section{Local solar PV innovation, market share and exports}

We now turn to assessing the possibility that there may have been short-term benefits of the Indian solar LCRs. For this analysis, we rely on a subset of the indicators commonly used in the innovation systems, catching up and related diversification literatures: domestic production, employment and patents (some of the relevant literature and metrics are summarized in the Methods section and the Supplementary Note 6). We do this by exploring the extent to which this policy was associated with positive or negative local manufacturing and innovation outcomes. There is no perfect set of metrics to assess domestic manufacturing and innovation capacity, so we selected a subset of the most commonly used indicators in the key literatures mentioned above, including solar PV patenting as a proxy for innovation capacity (Fig. 4a,b), market share of Indian firms (Fig. 4c) and exports from India (Fig. 4d). We therefore account for three major market developments-innovation, market share and exports-of Indian solar firms. The limitations of such indicator-based analysis and our inability to fully attribute changes in the indicators to the LCR are discussed in the Supplementary Note 6.

We find that solar PV patents in India have increased substantially from 2010 to 2019 and in 2015 almost reached the level of foreign patents (Fig. 4a). This analysis accounts for all solar patents filed in India from 1997 to 2019 by using web scraping to glean the data directly from the Indian patent office and using more than 284 distinct patent codes to identify solar PV system components. Figure $4 \mathrm{a}$ illustrates that the filing of solar PV-related patents by inventors based abroad started growing in 2010, coinciding with the growth in solar PV deployment in India under the first phase of the NSM. The number of patents by inventors based in India started increasing more rapidly around time the LCR policy was introduced in 2014. It should also be noted that the cell and balance of system $(\mathrm{BoS})$ inventions - the latter containing patents related to the panel, electronics and energy storage-were of equal importance for foreign inventors ( $50 \%$ and $50 \%$, respectively), whereas patents by Indian inventors were predominantly $(>70 \%)$ on BoS (or combination) topics (Fig. 4b).

In terms of market share, between 2014 and 2018 the imported volume of solar PV panels increased by roughly a factor of seven, 
Table 2 | Effect of LCRs on bid price

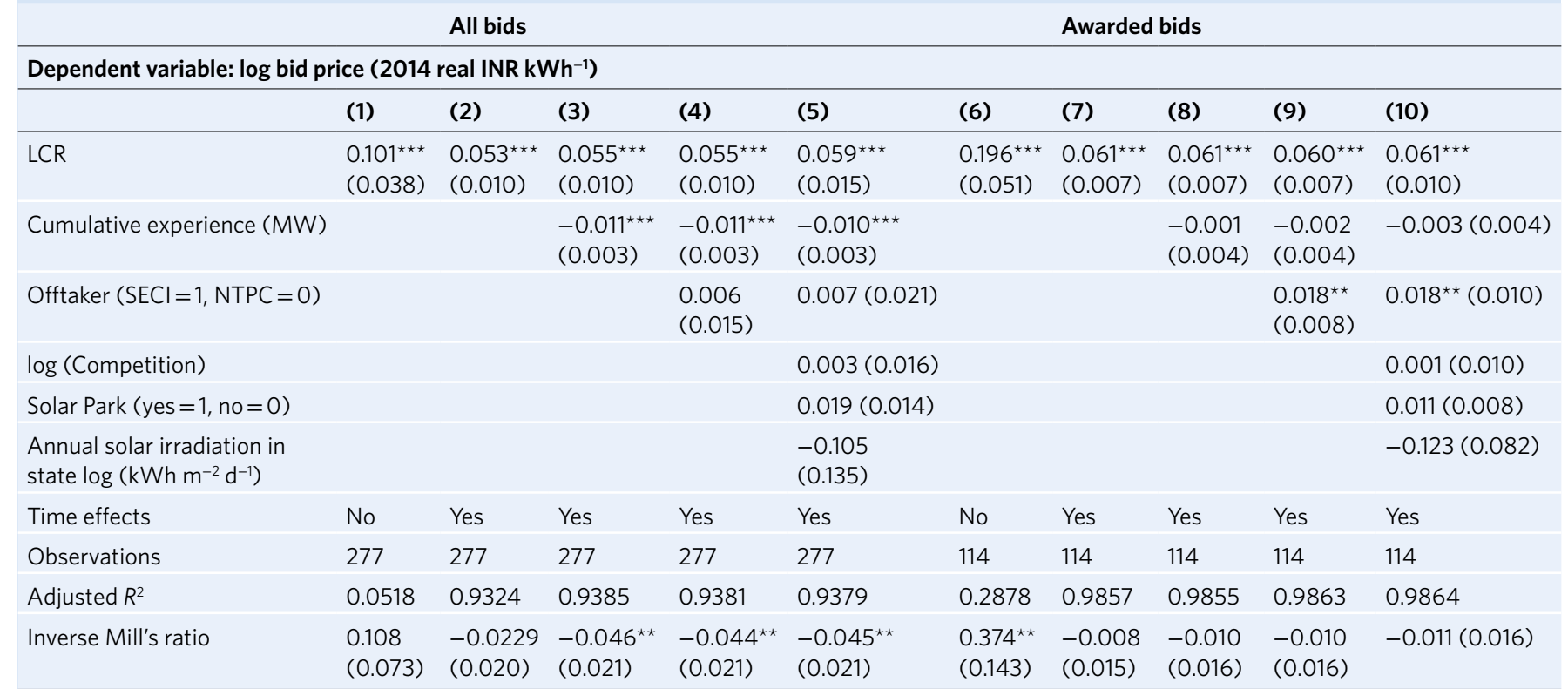

LCR is a dummy variable that switches from 0 to 1 if there were LCRs in the auction. Cumulative experience refers to the projects that the developer acquired in the auctions covered by our dataset before bidding for this project (inverse hyperbolic sine transformed cumulative MW). Offtaker refers to the utility buying the electricity (dummy with SECI =1, otherwise electricity bought by NTPC). Competition is a measure of how much capacity firms bid in relation to auctioned-off capacity. Standard error in parentheses. ${ }^{\star} p<0.10^{* *} p<0.05^{\star \star *} p<0.01$

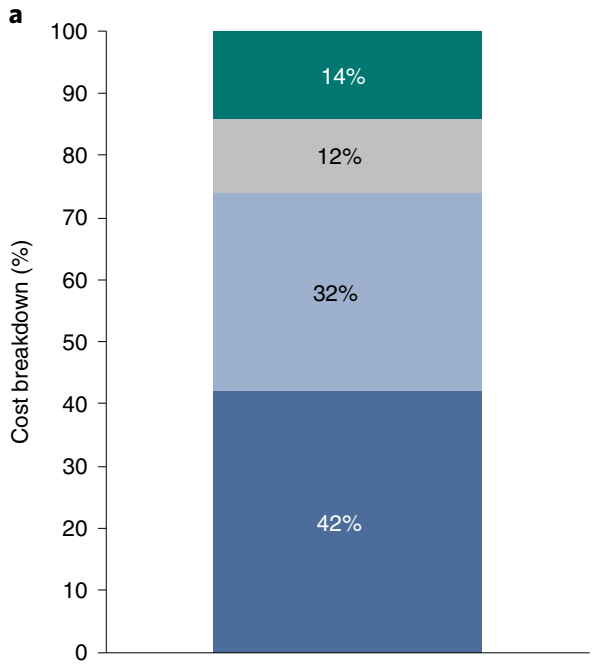

Module b

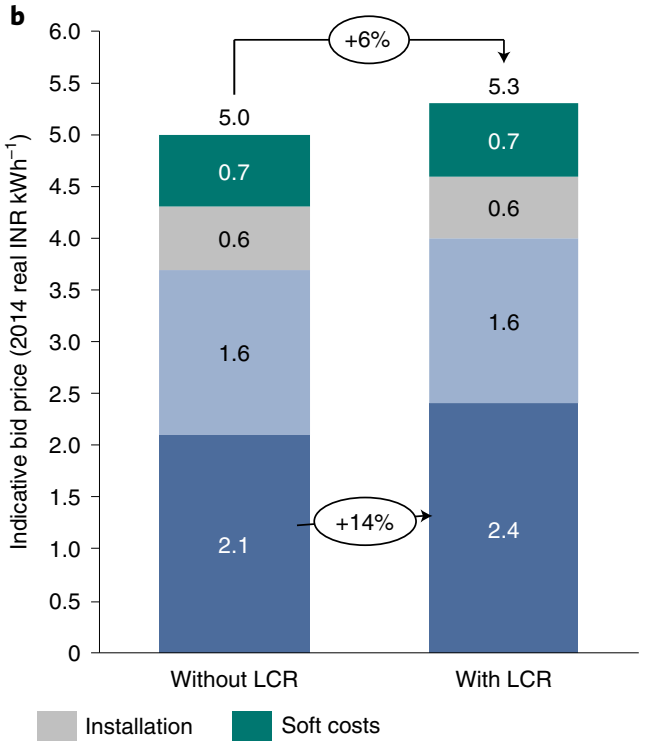

Fig. 3 | Utility solar PV cost breakdown and bid prices. a, Detailed cost breakdown of utility-scale solar PV in India. b, Indicative bid price increase due to introduction of LCRs on component level based on IRENA ${ }^{29}$ and our own calculations. As the module contributes $42 \%$ of the cost of utility-scale PV projects (a), a $6 \%$ overall increase in bid prices from non-LCR auctions to LCR auctions indicates that the module was $14 \%$ more expensive $(14 \% \times 42 \%=6 \%)(\mathbf{b})$. This calculation makes the simplifying but reasonable assumption that differences in bid prices are purely driven by differences in module cost (and not, for instance, by higher financing cost).

from a capacity of $\sim 1.3 \mathrm{GW}$ to one of $9.3 \mathrm{GW}$. Domestic production in India also increased fourfold, from $0.2 \mathrm{GW}$ to $0.8 \mathrm{GW}$ (Fig. 4c). While it is hard to attribute the acceleration of solar PV panel production in India solely to the LCR, the very large increase in the domestic manufacturing of solar panels manufactured in India is difficult to explain without LCRs. The reason for this is that Indian panels are not competitive based on price and track record, since they have not been deployed at large enough scale or for long enough to see whether they have comparable lifetimes and performances ${ }^{35}$. In addition, the increased capacity of Indian manufacturing was primarily used for the domestic market, as exports from India did not increase over the study horizon (Fig. 4d). However, it should be noted that Indian exports are likely to be a secondary goal when it comes to India, given that there are already very competitive international suppliers.

\section{Discussion}

The first part of our analysis investigated the cost associated with the LCR policy in India under the second phase of the National Solar Mission (2014-2017), in which LCR requirements were binding- 
a

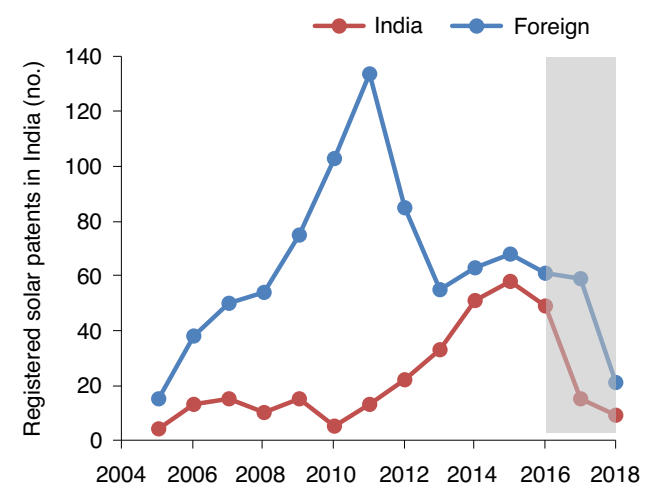

c

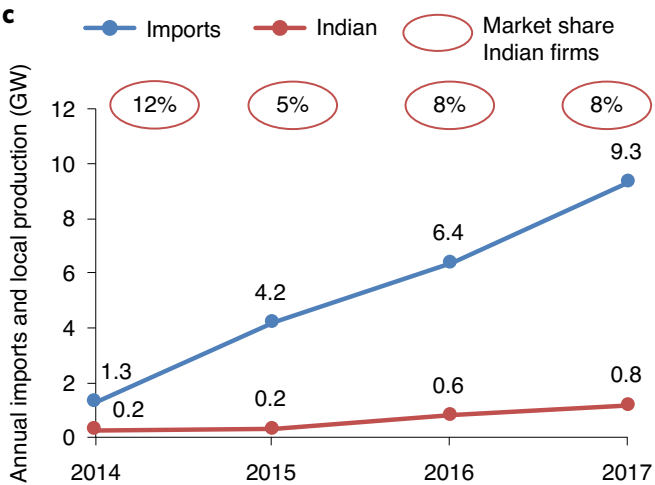

b

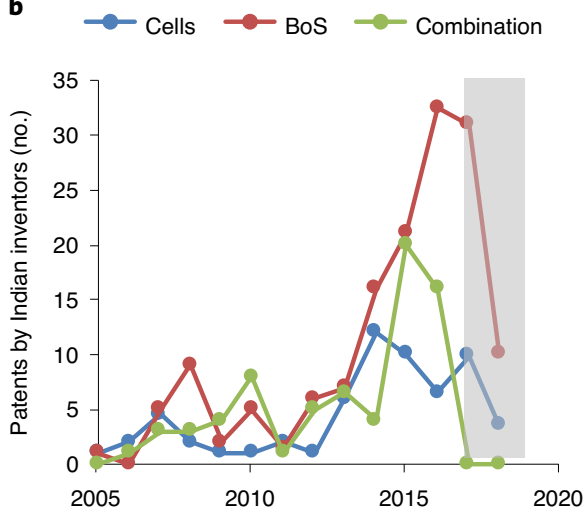

d

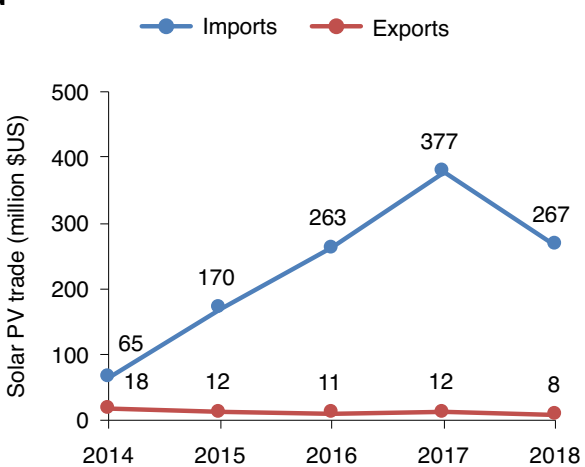

Fig. 4 | Solar PV patents, imports, exports and local production. a,b, Registered solar patents in India by origin (a) and patents filed by Indian inventors (b) as a function of time. The Indian patent office does not provide citations, so we cannot weight the patents by citation count. The drop beginning in 2016-2018 (shaded in grey) is due to the delays in the patenting procedure and database updates. The solar PV category 'combinations' refers to innovations that cannot be neatly sorted into either BoS or cells but combine both elements. We employ a typology from a recent, comprehensive review of IPC terms and their correspondence to PV system components published previously ${ }^{49}$. This typology covers 284 distinct IPC codes in seven groups: cells, panels, electronics, energy storage, monitoring/testing, devices and combined. c, Annual solar PV imports and local production. Data are based on Directorate General of Trade Remedies investigation on the imposition of safeguards on solar PV cells and modules on behalf of five Indian solar producers. 'Market share Indian firms' refers to the total cell and module production in India ${ }^{55}$. d, Annual solar imports and exports in India. Data are based on United Nations Comtrade data ${ }^{50}$. Lines in all panels serve only as guides to the eye.

unlike the first phase (2010-2013). The second part of our analysis then briefly assessed the possible benefits of the LCR policy by using selected indicators to track the evolution of local solar PV innovation (using a comprehensive and refined patent analysis), domestic versus imported solar PV market share and solar PV exports from India.

Our empirical analysis includes a credible counterfactual and shows that the LCR policy resulted in a $\sim 6 \%$ per $\mathrm{kWh}$ increase in the cost of solar PV power generated from those projects when compared to similar projects not subjected to the same LCR policy. This cost increase adds up to between US\$69 million and US\$88 million per installed GW of solar PV under the LCR policy, an increase that is ultimately paid for by Indian taxpayers. In addition, we found that the realization rates between the projects falling under the two auction types did not differ, suggesting that the creation of LCRs did not defer the construction of solar PV generation capacity.

Since the introduction of the policy, the domestic solar PV patenting and domestic production indicators improved. Yet Indian firms did not increase exports to other countries in the observed time period, indicating that most of the panels are still used in the local market. It should also be noted that the relationship between LCRs and domestic innovation (proxied through patenting) cannot be fully attributed to the programme, since it reflects previous trends that had started before the implementation of the LCR policy.
Despite the protectionist LCR measures, the cost of domestic solar PV panels saw the same drop in percentage terms as that of international panels. Hence, the gap in the cost of solar PV panels manufactured in India versus imported-which we computed to be around 14\%-remained the same between 2014 and 2017, indicating that Indian manufacturers kept the same pace of cost reductions (presumably through innovation and economies of scale) as international manufacturers. This cost decrease shows that, despite protective measures, domestic players were also able to bring down costs substantially with experience over a short time frame. While this has not yet translated into greater exports, the rise of Mundra, a large-scale Indian solar PV manufacturer with an installed manufacturing capacity of $1.2 \mathrm{GW}$, means that this may change in the future.

The COVID-19 pandemic also holds important lessons for emerging and late-mover countries in solar PV. The pandemic has adversely affected India's solar supply chain and in particular has reduced the scheduled capacity additions for 2020. The reason for this is that the lack of domestic capacity in India results in a high reliance on Chinese imports. The pandemic has led to delays in the shipment of Chinese panels to India and delays in solar project development. The Ministry for New and Renewable Energy (MNRE) has already urged Indian states to further support the development of domestic manufacturing hubs amidst the pandemic ${ }^{36}$. Hence, supply chain reliability concerns to meet national power generation 
goals need to be factored into the economic analysis by policymakers and project developers. Future work could expand our analysis on the short-term cost of LCRs to investigate the long-term benefits of resilience that could stem from diversifying supply chains not only in solar but also in other energy technologies where there is a substantial concentration of supply.

In addition, future work should explore whether the speed of completion (and not just the realization rates) of projects subject to LCR differed from those not subject to LCRs. In addition, while India abolished LCRs in 2017, the government found a way via public procurement to craft a policy that closely resembles LCR policy but is compliant with WTO rules. This will allow future research to more closely investigate the medium- to long-term effects of such policies. In addition, future work should delve into the broader context, such as geographic proximity to major exporters and international market prices, in which LCRs are enacted and its effect on the impact of LCR on domestic manufacturing and other indicators of interest. Lastly, in various countries consolidation only occurred after smaller, inefficient firms were driven out of the market after LCRs were phased out. Thus, future research will be able to more accurately quantify the benefits of such policies by considering longer time frames.

Understanding these possible benefits in greater detail will be critical, since second- and third-mover developing and emerging economies need to understand how and under what conditions they can reap a sufficiently large share of the burgeoning low-carbon technologies market.

\section{Methods}

Model. An ideal experimental set-up to study the effect of LCRs on bid prices would include (at least) two identical countries, completely independent of each other, with an auction scheme identical apart from the LCR feature. Any price difference that emerged between the two auction schemes could then be fully attributed to the differences in the LCR feature. Even better would be to include additional identical countries with varying levels of stringency in the level of the LCRs (in weight, value or number of components), to study whether there are discontinuities in bid prices that seem to be attributable to increasing levels of LCR stringency. For instance, one might expect a non-linear increase in bid prices if very high levels of LCRs (say, 95\%) were introduced given that the manufacturing capabilities for wafers would be near zero in India ${ }^{35}$.

The Indian case comes close to an ideal policy experiment given that many tendered capacities were distributed between LCR and non-LCR auctions in similar geographic areas-albeit not always equally in terms of capacity. Importantly, firms were free to bid in both LCR and open auctions, and many firms submitted bids in both auction windows. However, to address the possible remaining issue of selection bias (that is, firms self-selecting into auctions with or without LCRs), we divide firms into two groups: firms that only bid in auctions without LCRs (59 firms, 134 bids) and firms that bid in both auction types, open and closed ( 26 firms, 143 bids). The data used in the study come from various sources from the Indian government and firm-level data from Mergent Intellect (described in more detail in the Data section).

We considered using a multinomial selection model that would divide firms into three groups: those that only bid in auctions with LCRs, those that only bid in auctions without LCRs and those that bid in both auction types. However, since there are only seven firms in the category of 'only LCR auctions', we were unable to run the model. Yet we believe that the main question is whether a firm bid in an LCR auction, because it indicates whether the firm has sufficient local knowledge to either liaise with a local manufacturer or to use its own existing manufacturing facilities. Firms that only bid in the open auction, in contrast, could merely import the required parts. Hence, we expect there to be systematic differences between these two groups.

Thus, we test whether firms that do not bid in the LCR category are different from those that do bid in the LCR category. It could be, for instance, that firms that bid in LCR auctions have more experience in local development than firms that only bid in the open auctions (where there are no restrictions in using imported material). Similarly, firms that only bid in the open auctions might be able to more effectively exploit economies of scale by producing solar PV cells and modules for several markets (for example, Canadian Solar, which has manufacturing capabilities in China).

In addition to using standard ordinary least squares regressions, we therefore make use of a Heckman regression model, which accounts for this possible selection bias. Heckman's 1979 seminal paper proposes a two-step statistical approach $^{37}$. In the first step, an economic model is defined in which plausible factors for the probability of falling into (in our case) either Group 1 or 2 are considered. This is modelled as a probit regression,

$$
\operatorname{Pr}(G=1 \mid Z)=\Phi(Z b)
$$

where $G$ indicates whether the firm belongs to Group 1 ( $G=0$ otherwise), $Z$ is a vector of explanatory variables, $b$ is a vector of unknown parameters and $\Phi$ is the cumulative distribution function of the standard normal distribution. The explanatory variables we consider are the number of employees of a given firm, whether it is a state-owned enterprise (SOE) and whether the firm is itself a manufacturer or is merely a project developer (an indication of the degree of vertical integration). We also consider whether the firm is primarily focused on energy or merely attempts to diversify from an unrelated field, indicating limited technical experience, and whether the company already bid in the NSM Phase I. The latter factor captures advantages that firms might have in the NSM Phase II due to prior experience with the auction system.

The second stage of the Heckman model then uses the probability that a firm will self-select into Group 1, based on its characteristics, by including that probability as an explanatory variable in the ordinary least squares regression.

For our standard ordinary least squares and Heckman regression model, we also created a number of explanatory variables that we assume influence bid price. We recognize that competition differed substantially between rounds and was on average twice as high in open auctions as in LCR auctions (as measured by our variable defined in equation (2)). Firms are likely to anticipate, or at least have beliefs about, the level of competition in an upcoming auction round, which leads them to adapt their bids accordingly (that is, to make higher bids when less competition is expected; this is well documented in the literature ${ }^{38}$ ). In order to exclude the possibility that bids under LCR regulation are higher solely due to this effect, we control for the degree of competition within each round. Therefore, we define the competition for each tender as follows:

$$
\text { Competition }_{r}=\frac{\sum_{n=1}^{N} B_{r}}{A C_{r}}
$$

where $B$ is the capacity in MW of each of the bids submitted for a particular auction round $r, \mathrm{AC}$ is the total capacity in MW auctioned in round $r$ and $N$ is the overall number of bids received for each auction round $r$. For instance, if $20 \mathrm{MW}$ are auctioned off and firms submit $100 \mathrm{MW}$ in bids, the competition would be 5 .

We also include the cumulative installed capacity of each developer within the auction windows we cover to account for learning-by-doing of the developers and capacity building (for example, through greater local knowledge and connection to suppliers $)^{39,40}$. Our time dummy controls for exogenous technological change, such as decrease in the cost of solar PV modules and other equipment over time, that is not directly related to the deployment in India (that is, exogenous technical progress) ${ }^{41}$. We do not include a state dummy as the variable is correlated too strongly with our time dummy (as certain states only conducted auctions in specific years, leading to high multicollinearity). We do, however, include the mean solar irradiation (annual average $\mathrm{kWh} \mathrm{m}^{-2} \mathrm{~d}^{-1}$ ) per state to control for differences in the solar resources across different states (we also use the maximum solar irradiation for each state as a robustness check, which does not affect the results ${ }^{42}$ ).

In addition, we include a dummy for the utility that purchases the electricity generated by the awarded projects. It is well documented that the financial solvency of the utility buying the electricity (that is, the offtaker) is an important factor in assessing the risk associated with a project (that is, if an offtaker is less financially stable, the risk of a default increases, making capital more expensive, which in turn increases the cost of power ${ }^{43}$ ). Lastly, we consider whether a PV project being in a solar park has an effect on bid price. Solar parks are designated areas where environmental impact assessment, land procurement and interconnection are already taken care of. However, these increased costs may be reflected in the land price for the solar projects. By differentiating between solar parks and normal land, we are able to capture the price differences between the two approaches.

Thus, we use the following specification to study the effect of LCRs on bid price:

$$
\begin{aligned}
\operatorname{bid}_{i} & =\alpha+\beta_{1} \mathrm{LCR}_{r}+\beta_{2} \text { Competition }_{r}+\beta_{3} \text { Year }+\beta_{4} \mathrm{Cum}_{\mathrm{MW}} \\
& +\beta_{5} \text { Offtaker }+\beta_{6} \text { Solar park }+\beta_{7} \mathrm{Sol}+\varepsilon_{i}
\end{aligned}
$$

where bid $_{i}$ is the individual bid of each firm, $r$ is the auction round, $\mathrm{LCR}_{r}$ is the dummy for whether local content was required or not in the auction, Year is the time dummy to control for temporal shocks, $\mathrm{Cum}_{\mathrm{MW}}$ is the cumulative installed capacity prior to the given auction in the NSM Phase II, Offtaker is a dummy for the utility buying the power $(1=$ SECI, $0=$ NTPC), Solar park indicates whether the project is within a solar park, Sol refers to the annualized average solar resources $\left(\mathrm{kWh} \mathrm{m}^{-2} \mathrm{~d}^{-1}\right)$ in each state and $\varepsilon_{i}$ is the error term. We also include an interaction term between LCR and our time dummy, to test whether the effect of LCRs changed over time.

Part of the auctioned capacity was tendered under the viability gap funding (VGF) scheme, where the government fixed a base power purchase agreement (PPA) price and companies could request a top-up on the existing base price to make their project financially viable. Since price-only auctions have been 
implemented in India, the bidders who quoted the lowest amount of VGF were awarded the contracts until the auctioned capacity was reached (it should be noted that bidders were allowed to quote a lower PPA tariff than proposed and waive the VGF, but this rarely happened). Given that the VGF is dispensed as a capacity-based payment at the beginning of the lifetime of a power plant instead of as a constant subsidy for each unit of electricity generated, we had to levelize the amount to compare the outcomes with the generic auction results, where the payments are made across the entire lifetime of the power plant. Therefore, we applied the following method, which is based on the commonly used levelized cost of electricity (LCOE) calculation ${ }^{44}$, to calculate levelized VGF:

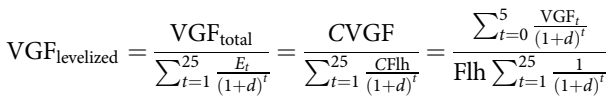

In equation (4), $E_{t}$ is the electricity generated in year $t, C$ is the project's capacity in MW and Flh is its full-load hours. We assume constant,

region-specific full-load hours, which can be found in ref. ${ }^{45}$. For bids that did not indicate the project's location in India, we assume a capacity factor of $20 \%$ and thus full-load hours of Flh $=1,752 \mathrm{~h}$. Moreover, we assume a discount rate of $d=10 \%$ and a plant life of $t=25$ years. With our approach, we are also able to capture the time value of money induced by the different VGF disbursement methods applied throughout Phase II (Supplementary Table 7; note that there was no VGF disbursement in Batch II). We then add the resulting levelized VGF support to the specific PPA price.

To estimate the possible range of values for the additional cost borne directly by the Indian government due to LCRs, we used the average estimates from our Heckman regression of the additional cost of power of LCR bids when compared to the open bids. We compute this overall cost to the Indian government via an NPV model in which we discount all future payments from the Indian government to solar power plant owners and compare the cost to the clean technology budget in India. We use discount rates of $10 \%, 12 \%$ and $14 \%$ and a capacity factor of $20 \%$ for the solar PV plants and a 25 -year running time based on REN21 (2018) data. These numbers are roughly similar (apart from possibly lower discount rates in this study) for other developing and emerging economies. These discount rates are based on information used by the Indian government for evaluating public projects ${ }^{46}$. Given the well-known challenges of choosing social discount rates $(\mathrm{SDRs})^{47}$, we perform a sensitivity analysis by varying the discount rate between $10 \%, 12 \%$ and $14 \%$. Taken together, these values for the SDRs encompass typical values of SDRs used in other developing and emerging economies, something that helps make our results more comparable to other countries ${ }^{46}$. We use the average real bid price from all open category auctions as our base price to calculate the additional cost of LCRs over the lifetime of an average solar project subject to LCRs.

In order to analyse the possible benefits of the LCR policy, we select a small set of indicators commonly used in the innovation systems and catching-up literature to determine whether a country is 'narrowing' the gap between the innovation leader and itself. While there are no perfect sets of metrics, we employ three different metrics commonly used in the innovation and economics literature: (1) domestic and international patent filings in the technology of interest ${ }^{40}$, (2) domestic production versus international imports ${ }^{5}$ and (3) exports to other countries from the country of interest ${ }^{4}$.

This analysis should be understood as correlational rather than causal, in contrast to the first part of our analysis. In addition, given how relatively recent the policy is, this analysis captures only short-term manufacturing and innovation effects. This is a limitation because some of the impacts of the policy, such as ongoing consolidation of the local industry through mergers and acquisitions, may take more time to materialize. Hence, the main contribution of this paper is the empirical assessment of the additional costs of LCRs, while the analysis of the possible benefits provides indicatory evidence of the evolution of important manufacturing and innovation metrics.

Data. In our analysis, we focus on the NSM Phase II auction results from 2014 to 2017. We did not include the bids and results from NSM Phase I since the majority of the projects $\left(61 \%\right.$ of total capacity deployed $\left.{ }^{48}\right)$ in the auction relied on thin film technology (as opposed to silicon panels), which was exempt from LCRs. Furthermore, we focused on the results of the PPA-based scheme and did not consider the EPC programme, which has a different focus: the auctioneer procures and owns the project and does not remunerate the electricity generated over 25 years to the project developer. The different remuneration mechanism, limited availability of data and different auction design elements, as well as different offtakers, hinder the comparability of the data. For the same reason, we neglect auctions conducted by state governments and focus solely on central government tenders conducted by either SECI or NTPC.

Contrary to most other countries conducting auctions, the Indian government shows a high degree of transparency in terms of publishing bids in the NSM Phase II auctions-including information on firms and the bid prices of both successful and unsuccessful applicants. We collected the data about the bid prices and the respective bidders from various government sources, either directly through governmental bodies (for example, SECI) or indirectly through different industry and reputable news sites, such as Mercom India or EQ International Magazine. We include all auction rounds of Phase II that had LCR regulations in place for a total of 28 auction windows across 10 Indian states. As shown in Supplementary Fig. 5, we intentionally excluded from the analysis the state-wise utility-scale PV tenders (around $14 \mathrm{GW}$ by September 2017). In addition, we exclude the central government EPC tenders $(1.6 \mathrm{GW})$ as well as the 'open category' rounds in central government auctions in which no counterfactual LCR auction took place (around 4.6 GW), such as the $100 \mathrm{MW}$ auction in Uttar Pradesh in Batch III.

We consider our dataset with 277 bids complete in terms of auction rounds, since LCRs were abolished on 14 December 2017 due to a ruling of the WTO, with NTPC's 250 MW Indian-wide auction being the last one under LCR regulation (the auction was later cancelled due to the negotiated phase-out of LCR). For further analysis, we consider the available submitted bids, rescale those to 2014 US dollar values to reflect inflation, and use logged bid values in our regression to normalize them. In summary, we consider bids with a total capacity of $21.7 \mathrm{GW}$, of which 18.7 GW were submitted in the open category and $3 \mathrm{GW}$ under the LCR scheme.

We also collect detailed firm data for all 85 firms within our sample. For each firm, we analyse whether it belongs to a bigger firm. Several firms are so-called special purpose vehicles, which are created merely to bid in a given auction. Given that these firms have access to the human, financial and technical capital of the bigger firm that they belong to, we use the firm characteristics of the parent company. In addition, we collect data on the employment numbers (which could be found for all firms, as opposed to sales numbers, which were unavailable for many privately owned firms), check whether the firm is an SOE and research whether the firms themselves have manufacturing capacities (that is, are vertically integrated). We analyse whether the firm had already bid in the first phase of the NSM, which might give firms a distinct advantage over newcomers due to experience with local regulations. We also check whether the main focus of the company is energy or whether it has just recently diversified its firm activities into energy. Lastly, we analyse whether the firm was founded in India or was registered abroad. We posit that all of these characteristics may influence whether a firm participates in a given auction (for example, we assume that firms that have local manufacturing capabilities are more likely to participate in LCR auctions).

We used solar irradiation maps from the National Renewable Energy Laboratory (NREL) and converted them via QGIS (version 2.8.14) into mean, maximum and minimum values for each state. The NREL dataset provides solar resource in India for surface cells of 0.1 degrees in both latitude and longitude, or nominally $10 \mathrm{~km}$ in size. The NREL calculations are based on data from the Meteosat-5 and Meteosat-7 geostationary meteorological satellites ${ }^{42}$.

Patent data were collected from the Indian Patent Database using web scraping methods (Python package Selenium), as the patent office does not offer an application programming interface (API). We employ a typology from a recent, comprehensive review of international patent classification (IPC) terms and their correspondence to PV system components published in Renewable and Sustainable Energy Reviews ${ }^{49}$. This typology covers 284 distinct IPC codes in seven groups: cells, panels, electronics, energy storage, monitoring/testing, devices and combined. Studies comparing global trends in patenting to track innovation normally rely on large patent databases such as the European patent database PATSTAT, which aggregates patent statistics across many domestic offices. However, for India the PATSTAT data are woefully incomplete, leading us to resort to web scraping techniques.

The data on domestic production and imports in Fig. $4 \mathrm{c}$ are based on the Directorate General of Trade Remedies investigation on the imposition of safeguards on solar PV cells and modules on behalf of five Indian solar producers. The export data in Fig. $4 \mathrm{~d}$ were exported from the global United Nations trade database Comtrade using the commodity code 'HS 854140', which describes 'photosensitive semi-conductor devices, including photovoltaic cells whether or not assembled in modules or made up into panels ${ }^{50}$.

\section{Data availability}

The data underlying this study are available via Mendeley at https://doi. org/10.17632/zbbrf6r5zn.2. Source data are provided with this paper.

Received: 19 July 2019; Accepted: 17 July 2020;

Published online: 31 August 2020

\section{References}

1. Renewables 2018 Global Status Report (REN21, 2018).

2. Altenburg, T. \& Assmann, C. (eds) Green Industrial Policy: Concept, Policies, Country Experiences (UN Environment, German Development Institute, 2017).

3. Building Competitive Green Industries: The Climate and Clean Technology Opportunity for Developing Countries (World Bank, 2014).

4. Binz, C. \& Anadon, L. D. Unrelated diversification in latecomer contexts: emergence of the Chinese solar photovoltaics industry. Environ. Innov. Soc. Transit. 28, 14-34 (2018).

5. Lewis, J. I. Technology acquisition and innovation in the developing world: wind turbine development in China and India. Stud. Comp. Int. Dev. 42, 208-232 (2007) 
6. Freeman, C. The 'National System of Innovation' in historical perspective. Camb. J. Econ. 19, 5-24 (1995).

7. Lee, K. The Art of Economic Catch-Up (Cambridge Univ. Press, 2019).

8. Hidalgo, C. A., Klinger, B., Barabasi, A.-L. \& Hausmann, R. The product space conditions the development of nations. Science 317, 482-487 (2007).

9. Nahm, J. Exploiting the implementation gap: policy divergence and industrial upgrading in China's wind and solar sectors. China Q. 231, 705-727 (2017)

10. Lewis, J. I. Green Innovation in China (Columbia Univ. Press, 2012); https:// doi.org/10.7312/lewi15330

11. Surana, K. \& Anadon, L. D. Public policy and financial resource mobilization for wind energy in developing countries: a comparison of approaches and outcomes in China and India. Glob. Environ. Change 35, 340-359 (2015).

12. Rodrik, D. Green industrial policy. Oxf. Rev. Econ. Policy 30, 469-491 (2014)

13. Matsuo, T. \& Schmidt, T. S. Managing tradeoffs in green industrial policies: the role of policy design. World Dev. 122, 1-40 (2019).

14. Johnson, O. Promoting green industrial development through local content requirements: India's National Solar Mission. Clim. Policy https://doi.org/10.1 080/14693062.2014.992296 (2015).

15. Stone, S., Messent, J. \& Flaig, D. Emerging Policy Issues: Localisation Barriers to Trade OECD Trade Policy Papers No.180 (OECD Publishing, 2015).

16. Joshi, S. \& Sharma, P. in Applications of the Input-Output Framework (ed. Mukhopadhyay, K.) 183-221 (Springer, 2018); https://doi.org/10.1007/978981-13-1507-7_8

17. OECD Trade Policy Note:The Economic Impact of Local Content Requirements (OECD, 2016)

18. Veloso, F. M. Understanding local content decisions: economic analysis and an application to the automobile industry. J. Reg. Sci. 46, 747-772 (2006).

19. Local Content Requirements and The Green Economy (UNCTAD, 2013).

20. Kuntze, J. \& Moerenhout, T. Local Content Requirements and the Renewable Energy Industry - A Good Match? (ICTSD, 2013).

21. Josefson, J. \& Rotar, A. Electricity regulation in the Russian Federation: overview. Thompson Reuters Practical Law http://uk.practicallaw. thomsonreuters.com (2018).

22. Jimeno, M., Grundner, C., Bruckmann, R. \& Hoeft, M. Enabling PV \& Wind in Argentina: A Framework Assessment of $P V$ \& Wind in Argentina (Eclareon $\mathrm{GmbH}, 2017$ ).

23. Cimino, C., Hufbauer, G. C. \& Schott, J. J. A Proposed Code to Discipline Local Content Requirements Policy Brief 14-6 (Peterson Institute for International Economics, 2014).

24. Lal, P. V. India prioritizes domestic products in plan for $12 \mathrm{GW}$ of new solar. $p v$ magazine (7 February 2019); https://www.pv-magazine-india.com/2019/02/07/ government-prioritizes-indian-products-in-plan-for-12-gw-of-new-solar

25. Böhringer, N. J. R., Rutherford, T. F. \& Wiggle, R. Green jobs and renewable electricity policies: employment impacts of Ontario's feed-in tariff. B. E. J. Econom. Anal. Policy 12, 1-40 (2012).

26. Mergent intellect. FTSE Russell https://www.ftserussell.com/data/mergentintellect (2019).

27. Quitzow, R. Assessing policy strategies for the promotion of environmental technologies: a review of India's National Solar Mission. Res. Policy 44, 233-243 (2015).

28. Dobrotkova, Z., Surana, K. \& Audinet, P. The price of solar energy: comparing competitive auctions for utility-scale solar PV in developing countries. Energy Policy 118, 133-148 (2018).

29. Renewable Power Generation Costs in 2017 (IRENA, 2018).

30. Pless, J. \& van Benthem, A. Pass-Through as a Test for Market Power: An Application to Solar Subsidies Working Paper No. 23260 (NBER, 2017); https://doi.org/10.3386/w23260

31. del Río, P. \& Gual, M. A. An integrated assessment of the feed-in tariff system in Spain. Energy Policy 35, 994-1012 (2007).

32. Di Dio, V., Favuzza, S., La Cascia, D., Massaro, F. \& Zizzo, G. Critical assessment of support for the evolution of photovoltaics and feed-in tariff(s) in Italy. Sustain. Energy Technol. Assess. 9, 95-104 (2015).

33. Bayer, B., Schäuble, D. \& Ferrari, M. International experiences with tender procedures for renewable energy - a comparison of current developments in Brazil, France, Italy and South Africa. Renew. Sustain. Energy Rev. 95, 305-327 (2018).

34. Ministry of New and Renewable Energy (MNRE, 2019); https://mnre.gov.in.

35. Kumar, S. Renewable and sustainable energy reviews solar photovoltaic energy progress in India: a review. Renew. Sustain. Energy Rev. 59, 927-939 (2016).

36. Mohanty, S. MNRE urges states to provide incentives to manufacturers. The Economic Times India (19 April 2020).

37. Heckman, J. Sample bias as a specification error. Econometrica 47, 153-162 (1979).
38. Haufe, M. \& Ehrhart, K. Auctions for renewable energy support - suitability, design, and first lessons learned. Energy Policy 121, 217-224 (2018).

39. Tang, T. Explaining technological change in the US wind industry: energy policies, technological learning, and collaboration. Energy Policy 120, 197-212 (2018).

40. Tang, T. \& Popp, D. The Learning Process and Technological Change in Wind Power: Evidence from China's CDM Wind Project Working Paper Series No. 4705 (CESifo, 2014).

41. Qiu, Y. \& Anadon, L. D. The price of wind power in China during its expansion: technology adoption, learning-by-doing, economies of scale, and manufacturing localization. Energy Econ. 34, 772-785 (2012).

42. Renewable Energy Data Explorer: India (NREL, 2020); https://maps.nrel.gov/ rede-india/

43. Eberhard, A., Gratwick, K., Morella, E. \& Antmann, P. Independent Power Projects in Sub-Saharan Africa: Lessons from Five Key Countries. Directions in Development - Energy and Mining (The World Bank, 2016); https://doi. org/10.1596/978-1-4648-0800-5

44. Branker, K., Pathak, M. J. M. \& Pearce, J. M. A review of solar photovoltaic levelized cost of electricity. Renew. Sustain. Energy Rev. 15, 4470-4482 (2011).

45. Gulagi, A., Choudhary, P., Bogdanov, D. \& Breyer, C. Electricity system based on $100 \%$ renewable energy for India and SAARC. PLoS ONE 12 e0180611 (2017).

46. Zhuang, J., Liang, Z., Lin, T. \& Guzman, F. De. Theory and Practice in the Choice of Social Discount Rate for Cost-Benefit Analysis: A Survey ERD Working Paper No. 94 (Asian Development Bank, 2007).

47. Nordhaus, W. D. A review of the Stern Review on the economics of climate change. J. Econ. Lit. 45, 703-724 (2007).

48. Sahoo, A. \& Shrimali, G. The effectiveness of domestic content criteria in India’s Solar Mission. Energy Policy 62, 1470-1480 (2013).

49. Shubbak, M. H. Advances in solar photovoltaics: Technology review and patent trends. Renew. Sustain. Energy Rev. 115, 109383 (2019).

50. Solar PV Commodity Codes (UN Comtrade, 2020).

51. Capacity \& generation. Climatescope http://global-climatescope.org/ capacity-generation (2018).

52. Coal-based Power Generation in India 2018 (India Infrastructure Research, 2018)

53. Krishna, S. India Installs $8.3 \mathrm{GW}$ of Solar in 2018. Mercom India https://mercomindia.com/india-installs-8-3-gw-solar-2018 (2019).

54. Hairat, M. K. \& Ghosh, S. 100 GW solar power in India by 2022 - a critical review. Renew. Sustain. Energy Rev. 73, 1041-1050 (2017).

55. Safeguard Investigation Concerning Imports of "Solar Cells Whether or Not Assembled in Modules or Panels" Into India - Final Findings (Directorate General of Trade Remedies, 2017); http://www.dgtr.gov.in/sites/default/files/ Solar-Final_Finding-English_0.pdf

\section{Acknowledgements}

Thanks to N. Tobis for support with web scraping the patent data. This work was supported by the European Union's Horizon 2020 research and innovation programme project INNOPATHS (Grant agreement no. 730403), the Department of Land Economy and the School of Humanities and Social Sciences, University of Cambridge and the Heinrich Böll Foundation.

\section{Author contributions}

B.P., V.A., A.K. and L.D.A. were responsible for developing the research idea. V.A. was responsible for collecting the auction data and B.P. collected all other data, such as patent data. B.P. did the empirical analysis. B.P., V.A., A.K. and L.D.A. were responsible for interpreting the outputs from the empirical analysis. B.P. wrote the manuscript with support from V.A., and B.P., V.A., A.K. and L.D.A. edited the final draft.

\section{Competing interests}

The authors declare no competing interests.

\section{Additional information}

Supplementary information is available for this paper at https://doi.org/10.1038/ s41560-020-0677-7.

Correspondence and requests for materials should be addressed to A.K.

Reprints and permissions information is available at www.nature.com/reprints.

Publisher's note Springer Nature remains neutral with regard to jurisdictional claims in published maps and institutional affiliations.

(c) The Author(s), under exclusive licence to Springer Nature Limited 2020 